\title{
MESOSPHERIC 2-DAY WAVES OBSERVED SIMULTANEOUSLY IN THE EQUATORIAL AND LOW LATITUDES REGIONS OF BRAZIL
}

\author{
Lourivaldo Mota Lima', Amauri F. Medeiros², Ricardo A. Buriti², Paulo P. Batista ${ }^{3}$, \\ Barclay R. Clemesha ${ }^{3}$ and Hisao Takahashi ${ }^{3}$ \\ Recebido em 17 janeiro, 2006 / Aceito em 26 março, 2007 \\ Received on January 17, 2006 / Accepted on March 26, 2007
}

\begin{abstract}
Simultaneous observations of the atmospheric neutral winds in the mesosphere and lower thermosphere (MLT) by meteor radar have been carried out at São João do Cariri $\left(7.4^{\circ} \mathrm{S}, 36.5^{\circ} \mathrm{W}\right)$ and Cachoeira Paulista $\left(22.7^{\circ} \mathrm{S}, 45.0^{\circ} \mathrm{W}\right)$. From the wind variability we investigate the atmospheric planetary-scale quasi-two-day waves, which were present at both the sites during the winter of 2004 and summer of 2004/2005. The amplitude of the meridional component was larger than that of the zonal component, reaching a maximum value of $\sim 60 \mathrm{~m} / \mathrm{s}$ at the equatorial site and $\sim 25 \mathrm{~m} / \mathrm{s}$ at the low latitude site during the winter. During the January-February period the 2-day wave was very similar at the two sites, with a maximum amplitude of $\sim 50 \mathrm{~m} / \mathrm{s}$. The phase propagation with height shows a descending mode and upward energy propagation. The vertical wavelength estimated for Cachoeira Paulista (40-67 km) was longer than for São João do Cariri (30-35 km), for all of the observed events. Cross-spectral analysis showed a significant coherence between the quasi-two-day oscillations observed at the two sites. From the phase difference between the two sites we concluded that São João do Cariri leads Cachoeira Paulista. These results denote that amplitude peak at $36.5^{\circ} \mathrm{W}$ and subsequently at $45^{\circ} \mathrm{W}$, compatible with a westward propagating wave.
\end{abstract}

Keywords: quasi-2-day wave, planetary-waves, meteor radar, upper mesosphere.

RESUMO. Este trabalho tem como base medidas dos ventos da parte superior da mesosfera e da baixa termosfera obtidas simultaneamente através de radares meteóricos em São João do Cariri $\left(7.4^{\circ} \mathrm{S}, 36.5^{\circ} 0\right)$ e Cachoeira Paulista $\left(22.7^{\circ} \mathrm{S}, 45.0^{\circ} \mathrm{O}\right)$. As ondas atmostéricas de escala planetária com períodos próximos de 2 dias são investigadas, as quais estiveram presentes nos ventos das duas localidades durante 0 inverno de 2004 e verão de 2004/2005. As amplitudes das oscilações foram mais intensas na componente meridional, alcançando máximos de $\sim 60 \mathrm{~m} / \mathrm{s}$ na localidade equatorial e $\sim 25 \mathrm{~m} / \mathrm{s}$ na de baixa latitude durante 0 inverno. Durante 0 período de janeiro-fevereiro a onda de 2 dias mostrou-se similar em ambas as localidades, com amplitude máxima de $\sim 50 \mathrm{~m} / \mathrm{s}$. A propagação de fase com a altura foi descendente, compatível com propagação ascendente de energia. Os comprimentos de onda verticais estimados para Cachoeira Paulista (40-67 km) foram maiores do que para São João do Cariri (30-35 km). Análises de espectro cruzado mostraram coerência significativa entre as oscilações de 2 dias nas duas localidades. Da diferença de fase entre as duas localidades verificou-se que os máximos em São João do Cariri (36,50) ocorrem antes do que os de Cachoeira Paulista (450), indicando propagação para a direção oeste.

Palavras-chave: onda de quase 2 dias, ondas planetárias, radar meteórico, mesosfera superior.

\footnotetext{
${ }^{1}$ Departamento de Física/CCT, Universidade Estadual da Paraíba (UEPB), Rua Juvêncio Arruda, s/n, Bodocongó - 58109-790 Campina Grande, PB, Brasil. Tel.: (83) 3315-3371 - E-mail: Imlima@uepb.edu.br

2Universidade Federal de Campina Grande (UFCG), Av. Aprígio Veloso, 882, Bloco CY, Bodocongó - 58109-970 Campina Grande, PB, Brasil. Tel.: (83) 3310-1196 -E-mails: afragoso@df.ufcg.edu.br; rburiti@df.ufcg.edu.br

3 Instituto Nacional de Pesquisas Espaciais (INPE), Av. dos Astronautas, 1758 - 12245-970 São José dos Campos, SP, Brasil. Tel.: (12) 3945-7143; Fax: (12) 3945-6740

-E-mails: ppbatista@laser.inpe.br; bclem@laser.inpe.br; hisaotak@laser.inpe.br
} 


\section{INTRODUCTION}

The well-known quasi-two-day wave is a prominent feature of the mesosphere and lower thermosphere (MLT) regions. This wave is a planetary scale oscillation that migrates westward, which maximizes soon after the summer solstice and which has been observed by ground-based and satellite techniques. Quasi-two-day waves are those oscillations with periods between 40-60 h and, in general, their amplitudes for the meridional wind component are greater than for the zonal at middle and high latitudes. In the Southern summer Hemisphere, the wave period is close to $48 \mathrm{~h}$ (e.g., Craig \& Elford, 1981), while in the Northern summer Hemisphere the wave period is found to be more variable, ranging from 43 h to 53 h (e.g., Muller \& Nelson, 1978; Thayaparan et al., 1997). Equatorial and low latitude observations have revealed the presence of this wave during the boreal and austral summers as well (Harris \& Vincent, 1993; Gurubaran et al., 2001; Lima et al., 2004).

Most studies have used simultaneous radar and satellite measurements to determine the zonal structure of the wave. In the Southern Hemisphere the zonal wavenumber 3 prevails (Rodgers \& Prata, 1981; Thayaparan et al., 1997; Limpasuvan $\&$ Wu, 2003). In the Northern Hemisphere, zonal wavenumbers between 2 and 5 have been reported, with wavenumbers 3 and 4 being the more important (Meek et al., 1996; Thayaparan et al., 1997).

The quasi-two-day wave was interpreted as a manifestation of the Rossby-gravity $(3,0)$ normal mode, in that the eigenstructure exhibits a predominant maximum in the meridional wind component at the equator. On the other hand, the zonal component passes through a node at the equator and is dominated by meridional component up to mi-latitudes (Salby, 1981). Using a mechanical model based on primitive equations, realistic background winds and analytic temperatures, Salby (1981) showed that the $(3,0)$ mode produces a significant response in the summer mesosphere. Hagan et al. (1993) performed a succession of numerical experiments using a linearized spectral model that includes realistic wind and temperature fields and dissipation effects, and also found a response to the Rossby normal mode in the lower thermosphere compatible with the observations. An alternative explanation was proposed by Plumb (1983). Based on a one-dimensional model, he showed that a 2-day wave with a zonal wavenumber 3 can be the product of zones of baroclinic instability above the summer stratospheric westward jet. Pfister (1985) extended the simulations to two dimensions and found peaks in the unstable wave growth at zonal wave numbers
$2-4$, with periods between 1.4 and 3 days. The possibility that the 2-day wave could be caused by a combination of the two mechanisms was suggested by Randel (1994) and, Norton \& Thuburn (1996). Salby \& Callaghan (2001) also explored the possibility that the 2-day wave could be produced by a mixture of the two excitation mechanisms. Hence, there is no conclusive evidence pointing to the source of the 2-day wave observed at MLT region.

In the present study, we investigate some aspects of the quasi-two-day wave observed in the horizontal winds obtained simultaneously in the equatorial and low latitudes MLT regions of the Southern Hemisphere, during winter 2004 and summer 2004/2005. The data and results are important since this comparison has not been previously done in this zone. In this way, further insights are supplied to better understand the relationship between 2-day wave and the zonal mean circulation in the MLT region.

\section{METEOR WINDS AND DATA ANALYSIS}

This study is based on hourly mean wind measurements collected simultaneously over São João do Cariri $\left(7.4^{\circ} \mathrm{S}, 36.5^{\circ} \mathrm{W}\right)$ and Cachoeira Paulista $\left(22.7^{\circ} \mathrm{S}, 45^{\circ} \mathrm{W}\right)$, Brazil, estimated in seven height intervals of $4 \mathrm{~km}$ thickness, separated by $3 \mathrm{~km}$, centered at $81,84,87,90,93,96$ and $99 \mathrm{~km}$. The data series cover the time interval from June 2004 to February 2005. The winds data were obtained by identical SKiYMET meteor radars. Both systems operate at a frequency of $35.24 \mathrm{MHz}$ and use an interferometric receiver antenna array. From the relative phases of the signals at the various antennas together with the echo range information, the position of the meteor is accurately located. The radial wind velocity is determined from the Doppler shift (Hocking et al., 2001).

The power spectra of the zonal and meridional winds at each atmospheric layer were estimated using a discrete Fourier transform for data time segments of 30 days. The zonal wind does not exhibit strong bursts in the 2-day oscillation during the period considered. Figures $1 \mathrm{~A}$ and $1 \mathrm{~B}$ show examples of power spectra for the layer centered at $90 \mathrm{~km}$ obtained from meridional winds over two sites for periods of 1-30 August 2004 (Fig. 1A - austral winter) and 15 January to 13 February 2005 (Fig. 1B - austral summer). We can see clearly in Figures $1 \mathrm{~A}$ and $1 \mathrm{~B}$, spectral peaks near the diurnal tidal period (1 cycle/day) and the quasi-2-day oscillation ( 0.5 cycle/day) for the two time intervals considered. For the first interval, the peak associated with the quasi-two-day oscillation at São João do Cariri is more intense than that for Cachoeira Paulista, however, during austral summer the peaks at both sites are similar, indicating that during the austral winter the 
quasi-2-day oscillation was more intense in the equatorial region than at lower latitudes, and during austral summer their intensities were similar.

(A)

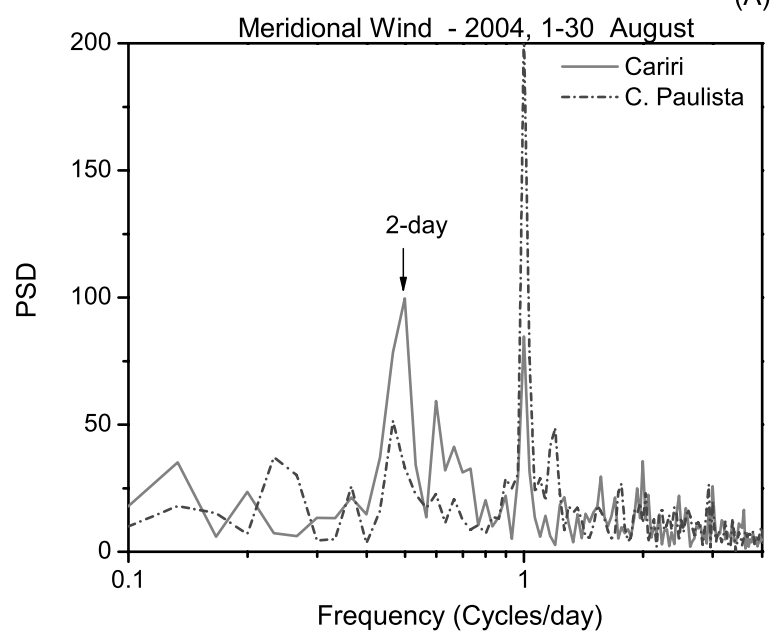

(B)

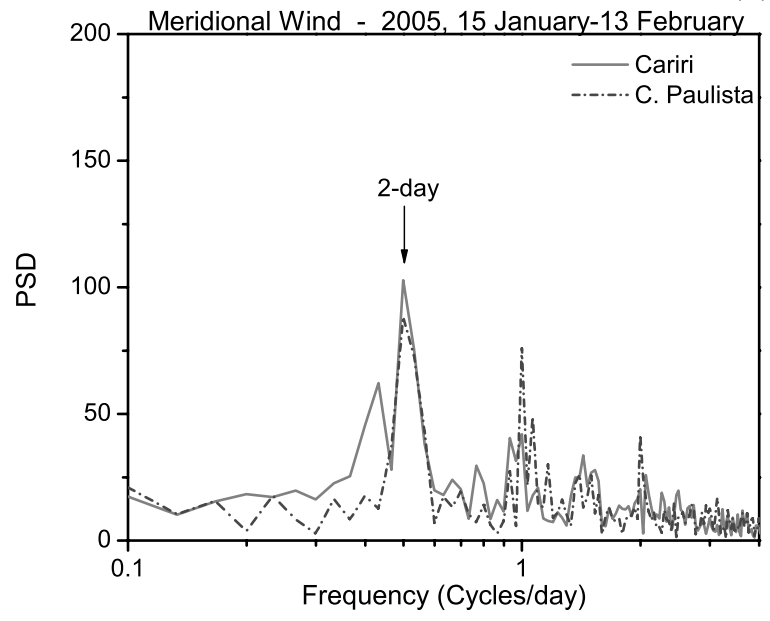

Figure 1 - Power spectra for 90 km meridional winds over São João do Cariri (solid line) and Cachoeira Paulista (dash dot line), A) for the periods 1-30 August 2004 and B) 15 January to 13 February 2005.

To examine the amplitude intensifications of the quasi-2-day wave, the wind data from June 2004 to February 2005 for both sites were subjected to harmonic analysis. The analysis was performed for sliding four-day segments stepped by one day. The quasi-2-day amplitudes and phases of the zonal and meridional wind components were fitted in a least-mean-square sense, assuming that semidiurnal, diurnal and quasi-2-day oscillations were present in the horizontal wind components at all times. Figures $2 \mathrm{~A}$ and $2 \mathrm{~B}$ shows the amplitudes of the 2-day oscillations for both the zonal and meridional components for altitude range centered at $90 \mathrm{~km}$ in the time interval from June 2004 to February 2005. It can be seen from these figures that the 2-day wave has maximum amplitude during the solstice months, i.e. for time intervals from about day 212 (July 30, 2004) to day 243 (August 30, 2004) and from about day 356 (December 21, 2004) to day 414 (February 17, 2005). As can be seen, as at other sites, during 2-day wave events the meridional amplitudes (Fig. 2A) were larger than the zonal (Fig. 2B, reaching maximum values of $\sim 60 / 25$ (winter) and $\sim 50 / 45 \mathrm{~m} / \mathrm{s}$ (summer) at São João do Cariri/Cachoeira Paulista. The meridional amplitude indicates the weaker presence of 2-day activity at other times of the year, mainly over São João do Cariri. In this paper, the Southern winter and summer occurrences of the 2-day wave will be analyzed only for the meridional component.

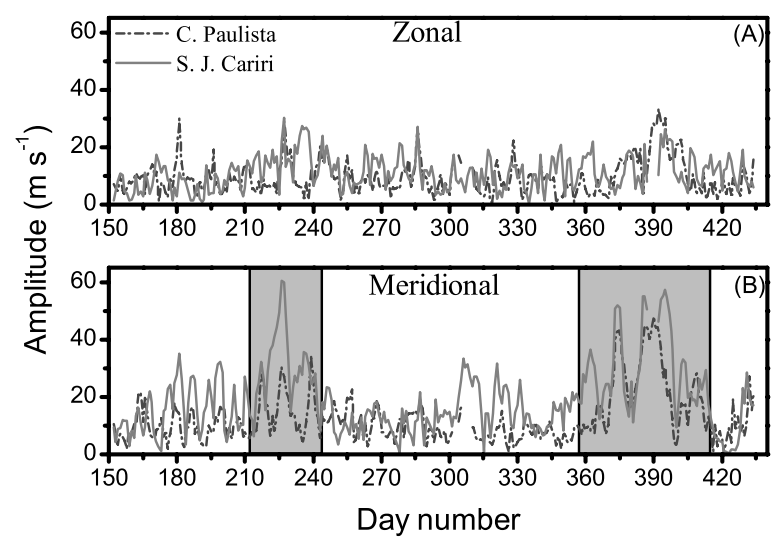

Figure 2 - Daily amplitudes of the 2-day oscillations at $90 \mathrm{~km}$ for São João do Cariri (solid line) and Cachoeira Paulista (dash dot line) for A) zonal and B) meridional components from June, 2004 to February, 2005.

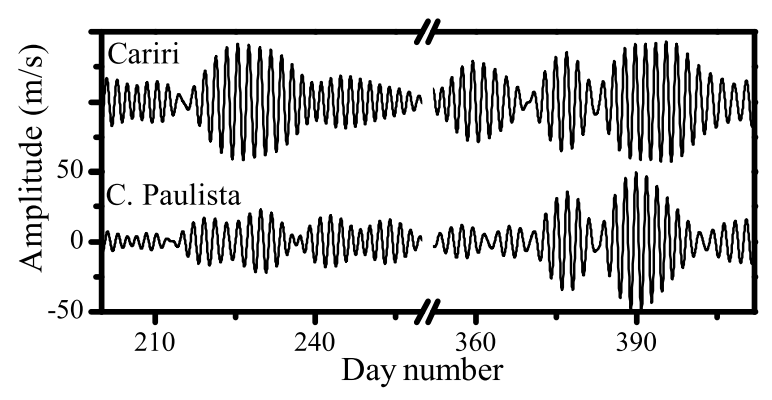

Figure 3 - Meridional component of the winds observed at $90 \mathrm{~km}$ for São João do Cariri and Cachoeira Paulista during 2004 winter and 2004/2005 summer. Data have been band-pass filtered to retain only periods between $42 \mathrm{~h}$ and $54 \mathrm{~h}$.

To investigate the behavior of the 2-day wave in the time domain, the meridional winds at the two sites were subjected to a band pass filter with cutoff periods of $42 \mathrm{~h}$ and $54 \mathrm{~h}$, since wave period is close to $48 \mathrm{~h}$ in the Southern summer Hemisphere. Figure 3 shows filtered winds for the 2-day wave observed at $90 \mathrm{~km}$ for Southern winter 2004 and Southern summer 2004/ 2005. As can be seen, during Southern winter 2004 the 2-day 
wave was more intense at the equatorial site than at the low latitude site, suggesting a leakage of the wave from the summer hemisphere to the winter hemisphere. During summer 2004/2005 the occurrence of the 2-day wave was very similar at the two sites, mainly during the interval from about day 370 to day 406 (January 04 to February 10). In general, the period of intense activity at the equatorial site was longer than at the low latitude site.

To display the behavior of the amplitude and phase of the 2day wave as a function of height, the results obtained by harmonic analysis, for meridional winds measured during the strongest events at both sites, are shown in Figures $4 A$ and $4 B$.

As can be seen in Figure 4A, in general, maximum amplitude values occur for heights around $90 \mathrm{~km}$ at both sites. The larger amplitude in the São João do Cariri data observed during interval from 226-229 (austral winter) is in accordance with suggesting of leakage of the 2-day wave from the Northern summer hemisphere to the Southern winter hemisphere. The behavior of the phase with height (Fig. 4B) are very similar for each of the three event periods and shows that the time of the maximum meridional wind, at both sites, is earlier at greater heights, suggesting a descending phase and upward energy propagation. From the phase structures, we estimate the vertical wavelengths. The results show that at Cachoeira Paulista the vertical wavelengths ( $\sim 41 \pm 2, \sim 41 \pm 2.4$, and $\sim 65 \pm 3.4 \mathrm{~km}$ ) were consistently larger than at São João do Cariri $(\sim 30 \pm 2.5, \sim 30 \pm 2$, and $\sim 35 \pm 2 \mathrm{~km}$ ) for all 3 strong events.

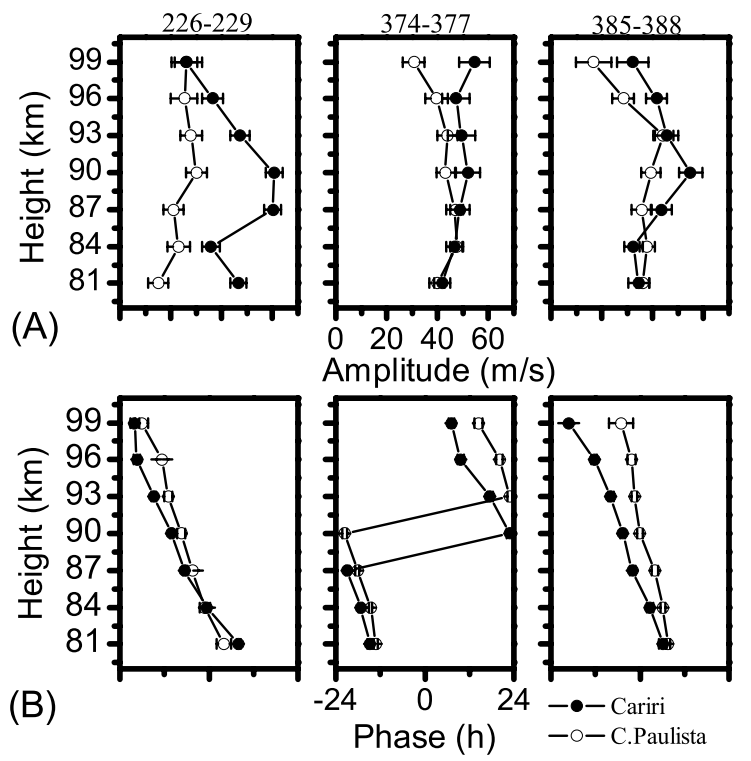

Figure 4 - Two-day wave meridional A) amplitude and B) phase as a function of height, for 3 groups of four days, obtained by harmonic analysis.

Cross-spectral analysis provides another way to explore the relation between the dynamics at São João do Cariri and Ca- choeira Paulista. Mean cross-spectra were computed for 7 equally spaced height intervals using 10-day meridional wind segments and the results for day intervals 226-235, 370-379 and 390-399, are shown in the Figure 5. The mean square coherence values are significant at periods near 2 days for all 3 segments considered. This means that, when a quasi-two-day peak in the spectrum appears at equatorial latitudes, it emerges at low latitudes too. From the phase plot it is possible to observe that on the average São João do Cariri leads Cachoeira Paulista, that is, the amplitude peak at $36.5^{\circ} \mathrm{W}$ and subsequently at $45^{\circ} \mathrm{W}$. Therefore, these results are consistent with westward propagation of the quasitwo-day wave.

\section{SUMMARY AND CONCLUSIONS}

Simultaneous observations of the meteor winds at São João do Cariri and Cachoeira Paulista, in the equatorial and low latitude MLT regions, respectively, have shown the presence of a 2-day wave during the winter of 2004 and the summer of 2004/2005. It is advantageous to use data from these two-stations, separated by $15^{\circ}$ in latitude, in order to compare and to resolve issues about the latitudinal dependence of the wave characteristics.

Spectral and harmonic analysis showed simultaneous quasitwo-day wave events in equatorial and low latitude wind data during August, 2004 and January-February, 2005. The meridional amplitudes were larger by factor of 2 than the zonal ones reaching maximum values of $\sim 60$ and $45 \mathrm{~m} / \mathrm{s}$ at equatorial site and, of $\sim 25$ and $50 \mathrm{~m} / \mathrm{s}$ at low latitude site, during austral winter and summer, respectively. Because the zonal amplification to be weak the 2-day analysis was focused on the meridional component.

Early observations from equatorial latitudes at Christmas Island $\left(2^{\circ} \mathrm{N}, 157^{\circ} \mathrm{W}\right)$ and from low latitudes at Kauai $\left(22^{\circ} \mathrm{N}\right.$, $160^{\circ} \mathrm{W}$ ), in the Northern Hemisphere and, at Townsville (19 $\mathrm{S}$, $147^{\circ} \mathrm{E}$ ) and at Cachoeira Paulista, in the Southern Hemisphere, displayed significant 2-day wave amplitudes during both solstices in both wind components (Harris \& Vincent, 1993; Fritts \& Isler, 1994; Craig et al., 1983; Lima et al., 2004). Significant amplitudes for $\sim 2$-day oscillations during winter solstices are predicted theoretically as being due to leakage of the 2-day wave across the equator from the summer hemisphere. In our analysis we observed that the August 2004 event was intense at the equatorial site and weak at the low latitude location, which is consistent with this suggestion. During January-February 2005, the 2-day wave was very similar at the two sites.

The vertical phase structure shows descending phase and the vertical wavelengths estimated for Cachoeira Paulista were Ionger 

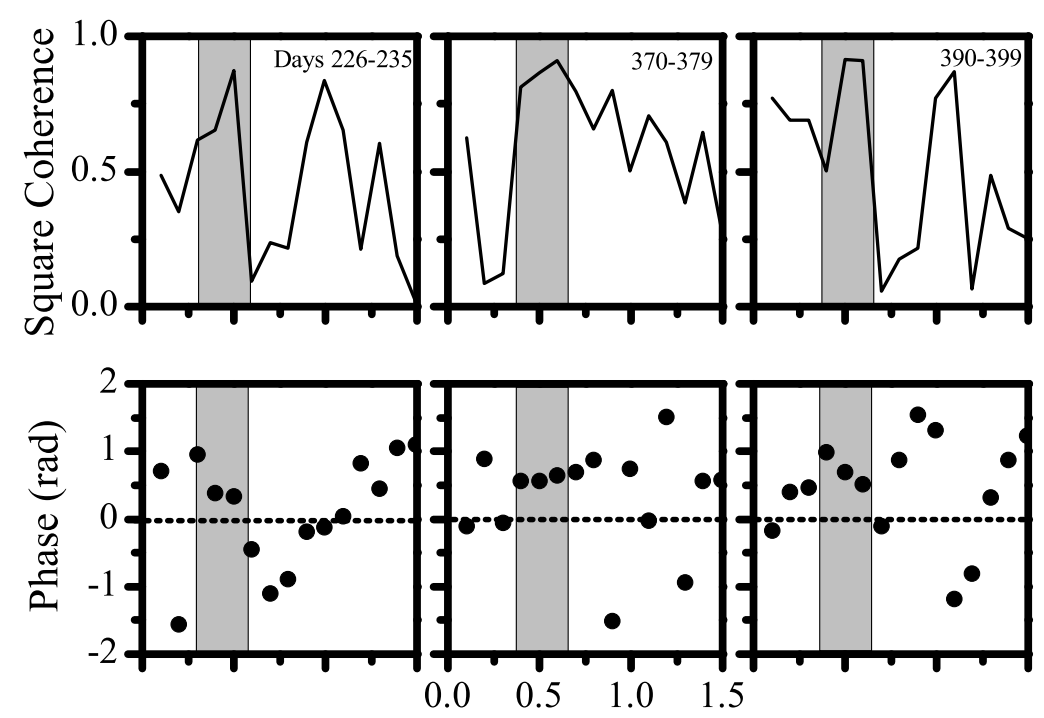

Frequency (cycles/day)

Figure $\mathbf{5}$ - Mean square coherence (top) and cross-spectral phase lag (bottom) between meridional wind measured at São João do Cariri and Cachoeira Paulista during 2004 winter and 2004/2005 summer, for 7 height intervals.

than for São João do Cariri, for all observed events. The vertical wavelengths take values from about 40 to $65 \mathrm{~km}$ at Cachoeira Paulista and from about 30 to $35 \mathrm{~km}$ at São João do Cariri. In recent investigation, Lima et al. (2004) found 2-day wave vertical wavelengths raging from 25 up to $100 \mathrm{~km}$ at Cachoeira Paulista, for three summer solstices. Our equatorial results are shorter than those found by Pancheva et al. (2004) that observed to be of $45 \mathrm{~km}$ at Ascension Island $\left(7.9^{\circ} \mathrm{S}, 14.4^{\circ} \mathrm{W}\right)$ from meteor radar winds and than that observed at Christmas Island $(\sim 70 \mathrm{~km})$ from MF radar winds (Harris \& Vincent, 1993). Vertical wavelengths for 2-day wave were found to be of 35-70 $\mathrm{km}$ at Tirunelveli (Gurubaran et al., 2001).

Cross-spectral analysis showed significant coherence between the quasi-two-day activities observed at the two sites, showing that when a quasi-two-day peak appears in the equatorial region it will most often be seen also at low latitudes. From the phase difference between the two sites, we observed that on average São João do Cariri leads Cachoeira Paulista. These results are compatible with a westward propagating wave.

It is important to conduct further studies to explain issues about interaction of the 2-day wave with mean wind flow as well as with others wave modes. Since vertical wind shear would to affect the vertical wavelength of the waves, it is possible that interactions between the 2-day wave and mean wind flow cause the latitudinal difference of the vertical wavelength observed.

\section{ACKNOWLEDGMENTS}

The present work was partially supported by the Conselho Nacional de Desenvolvimento Científico e Tecnológico, CNPq and the Fundação de Amparo à Pesquisa do Estado de São Paulo, FAPESP.

\section{REFERENCES}

CRAIG RL \& ELFORD WG. 1981. Observations of the quasi 2-day wave near $90 \mathrm{~km}$ altitude at Adelaide (35 $)$ ). J. Atmos. Terr. Phys., 41(10): 1051-1056.

CRAIG RL, VINCENT RA, KINGSLEY SP \& MULLER HG. 1983. Simultaneous observations of the quasi 2 -day wave in the northern and southern hemispheres. J. Atmos. Terr. Phys., 45(8-9): 539-541.

FRITTS DC \& ISLER JR. 1994. Mean motions and tidal and two-day structure and variability in the mesosphere and lower thermosphere over Hawaii. J. Atmos. Sci., 51(14): 2145-2164.

GURUBARAN S, SRIDHARAN S, RAMKUMAR TK \& RAJARAM R. 2001. The mesospheric quasi-2-day wave over Tirunelveli $\left(8.7^{\circ} \mathrm{N}\right)$. J. Atmos. Sol. Terr. Phys., 63(10): 975-985.

HAGAN ME, FORBES JM \& VIAL F. 1993. Numerical investigation of the propagation of the quasi-2-day wave into the lower thermosphere. J. Geophys. Res., 98(D12): 23193-23205.

HARRIS TJ \& VINCENT RA. 1993. The quasi-two-day observed in the equatorial middle atmosphere. J. Geophys. Res., 98(D6): 10.48110.490 . 
HOCKING WK, FULLER B \& VANDEPEER B. 2001. Real-time determination of meteor-related parameters utilizing modern digital technology. J. Atmos. Sol. Terr. Phys., 63(2-3): 155-169.

LIMA LM, BATISTA PP, TAKAHASHI H \& CLEMESHA BR. 2004. Quasitwo-day wave observed by meteor radar at $22.7^{\circ} \mathrm{S}$. J. Atmos. Sol. Terr. Phys., 66(6-9): 529-537.

LIMPASUVAN V \& WU DL. 2003. Two-day wave observations of UARS Microwave Limb Sounder mesospheric water vapor and temperature. J. Geophys. Res., 108(D10): ACL 4-1, CitelD 4307, D0I 10.1029/ 2002JD002903

MEEK CE, MANSON AH, FRANKE SJ, SINGER W, HOFFMANN P, CLARK RR, TSUDA T, NAKAMURA T, TSUTSUMI M, HAGAN M, FRITTS DC, ISLER J \& PORTNYAGIN YU I. 1996. Global study of northern hemisphere quasi 2-day wave events in recent summers near $90 \mathrm{~km}$ altitude. J. Atmos. Terr. Phys., 58(13): 1401-1412.

MULLER HG \& NELSON L. 1978. A traveling quasi 2-day wave in the meteor region. J. Atmos. Terr. Phys, 40(6): 761-766.

NORTON WA \& THUBURN J. 1996. The two-day wave in a middle atmosphere GCM. Geophys. Res. Lett., 23(16): 2113-2116.

PANCHEVAD, MITCHELL NJ \& YOUNGER PT. 2004. Meteor radar obser- vations of atmospheric waves in the equatorial mesosphere/lower thermosphere over Ascension Island. Ann. Geophys., 22(2): 387-404.

PFISTER L. 1985. Baroclinic instability of easterly jets with applications to the summer mesosphere. J. Atmos. Sci., 42(4): 313-330.

PLUMB RA. 1983. Baroclinic instability of the summer mesosphere: a mechanism for the quasi-two-day wave? J. Atmos. Sci, 40(1): 262-270.

RANDEL WJ. 1994. Observations of the 2-day wave in NCM stratospheric analyses. J. Atmos. Sci, 52(2): 306-313

RODGERS CD \& PRATA AJ. 1981. Evidence for a traveling two-day wave in the middle atmosphere. J. Geophys. Res., 86(C10): 9661-9664.

SALBY ML. 1981. The 2-day wave in the middle atmosphere - observations and theory. J. Geophys. Res., 86(C10): 9654-9660.

SALBY ML \& CALLAGHAN PF. 2001. Seasonal Amplification of the 2Day Wave: Relationship between Normal Mode and Instability. J. Atmos. Sci, 58(14): 1858-1869.

THAYAPARAN T, HOCKING WK, MACDOUGALL J, MANSON AH \& MEEK CE. 1997. Simultaneous observations of the 2-day wave at London $\left(43^{\circ} \mathrm{N}, 81^{\circ} \mathrm{W}\right)$ and Saskatoon $\left(52^{\circ} \mathrm{N}, 107^{\circ} \mathrm{W}\right)$ near $91 \mathrm{~km}$ altitude during the two years of 1993 and 1994. Ann. Geophys., 15(10): 1324-1339.

\section{NOTES ABOUT THE AUTHORS}

Lourivaldo Mota Lima is graduated in Physics by the Regional University of the Northeast (URNe), Brazil, obtained his MSc. Degree in Meteorology from Federal University of Paraíba (UFPB), Brazil, and his Ph.D. in Space Geophysics from National Institute for Space Research (INPE). Since 1991 is a professor of Physics Department at Paraíba University State (UEPB). His research interests include the upper atmospheric dynamics by meteor radar and airglow measurements.

Amauri Fragoso de Medeiros is a professor in the Physics at Federal University of Campina Grande (UFCG), Brazil. He is graduated in Physics at the Regional University of the Northeast (URNe), Brazil, obtained his MSc. Degree in Science Teaching from São Paulo University (USP), Brazil, and his Ph.D. in Space Geophysics from the National Institute for Space Research (INPE). His present research interests include the dynamics of the upper mesosphere using airglow and meteor radar experiments and irregularities in the ionosphere.

Ricardo Arlen Buriti received his BSc in Physical from Federal University of Paraíba (UFPB), Brazil. He obtained his MSc. in Physical Chemistry by the São Paulo University (USP), Brazil, and his Ph.D. in Space Geophysics from the National Institute for Space Research (INPE). He is a professor in the Physics at the Federal University of Campina Grande (UFCG), Brazil and his present research interests include the dynamics and chemistry of the upper mesosphere.

Paulo Prado Batista is graduated in Physics at the Federal University of Goiás (UFG), Brazil, and received his Master and Ph.D. in Space Sciences at the National Institute for Space Research (INPE). He is a researcher at the INPE and his areas of interest include the dynamics of the upper atmosphere, sporadic metal layers, long-term trends in the mesosphere, mesospheric-lower thermospheric temperature.

Barclay Robert Clemesha is BSc. in Physics at the University of London in 1957 and obtained his Ph.D. at the University of the West Indies in 1968. At the end of 1968 he moved to Brazil to work for the National Institute for Space Research (INPE), and has been there ever since. His present interests include the dynamics, airglow and chemistry of the upper mesosphere and lower thermosphere, using lidar, airglow and rocket experiments.

Hisao Takahashi is a researcher at the National Institute for Space Research (INPE) since 1970. He received his BSc. and MSc. in Physics at the Niigata University $(1968,1970)$ and obtained his Ph.D. in Space Sciences at the INPE (1980). His research interests include behavior studies of the airglow, dynamics and chemistry of the upper mesosphere and ionosphere. 